\title{
The effect of post-calving pain management with carprofen on stress, reproduction, and milk yield in cattle
}

\author{
Ramūnas Antanaitis, Aloyzas Januškauskas, Arūnas Rutkauskas, Henrikas Žilinskas \\ Lithuanian University of Health Sciences, Veterinary Academy, Large Animal Clinic, Kaunas, Lithuania
}

Received July 6, 2017

Accepted May 15, 2018

\begin{abstract}
Previous research has shown that the administration of non-steroidal anti-inflammatory drugs in postpartum cattle has the potential to be a viable way to improve productivity and reproduction, although further research is necessary to optimise recommendations for producers. The aim of this research was to determine the influence of carprofen on dairy cows using a number of different indices including stress, reproduction, and milk yield data. The experiment was carried out on 100 first-lactation dairy cows. The animals were divided into two groups. The treatment group $(\mathrm{TG}, \mathrm{n}=50)$ was given a subcutaneous injection of Rimadyl Cattle ${ }^{\circledR}(50 \mathrm{mg} / \mathrm{ml}$ of carprofen) up to one hour after calving. At the same time, the control group (CG, $\mathrm{n}=50)$ was given an injection of $0.9 \% \mathrm{NaCl}$. Blood tests were taken 2, 24, and $48 \mathrm{~h}$ after calving and tested using the fluorescence enzyme immunoassay method for cortisol analysis. At 305 days, the total milk yield was recorded for each cow. A computerised herd management program was used for data registration and analysis. Pregnancy was tested by ultrasound between 30 and 35 days after insemination. A subcutaneous injection of carprofen $(1.4 \mathrm{mg}$ per $1 \mathrm{~kg}$ of body weight) given one hour after parturition in first-lactation cows reduced the level of cortisol within $48 \mathrm{~h}$ after calving. During lactation (305 days in milk), the intervention increased the milk yield (252 $\mathrm{kg}$ ) and pregnancy rates $(8.5 \%)$, reduced the calving interval (43 days), and decreased the somatic cell count during the second, third, and fourth months after calving.
\end{abstract}

Milk yield, pregnancy rate, stress

Providing analgesia to a postpartum cow is not a common intervention following an unassisted calving, but may be used following dystocia, retained placenta membranes and is commonly used following a caesarean section. Behavioural, clinical, and production measures may all be used to indicate pain (Broom and Fraser 2007). Some trends in the behavioural, clinical, and production data suggest that the use of analgesics has a positive effect on the welfare of postpartum cows and on the milk yield of first-lactation animals. Pain management after parturition leads to earlier feed intake after calving, which may in turn lead to a higher milk yield in first-lactation animals (Stilwell et al. 2014). Non-steroidal anti-inflammatory drugs (NSAIDs) are frequently used as adjunctive therapy to antibiotics. Carprofen improves the general clinical condition by effective antipyrexia and restoration of reticulorumen motility.

Pain caused by parturition in animals requires more research in order to optimise the parturition process and reduce its negative consequences on health, welfare and productivity (Mainau and Manteca 2011). According to Paull et al. (2007), further work is needed to identify the influence of the time of administration of NSAIDs on the efficacy of combination treatment. Although analgesics are used in postpartum cows, evidence following from further studies is needed before a recommendation can be made (Stilwell et al. 2014). The administration of NSAIDs in postpartum cows has the potential to be a viable way to improve the productivity and potential longevity in commercial dairy farming, although again, further research is necessary to optimise the recommendations for

Address for correspondence:

Ramūnas Antanaitis

Large Animal Clinic

Lithuanian University of Health Sciences

A. Mickevičiaus g. 9, 44307 Kaunas, Lithuania

Phone: +37067349064

E-mail: ramunas.antanaitis@1smuni.lt

http://actavet.vfu.cz/ 
producers (Carpenter et al. 2016). Carprofen is a suitable analgesic for painful procedures in cattle (Stilwell et al. 2014)

In this study, we aimed to determine the effect of post-calving pain management with carprofen $(1.4 \mathrm{mg} / \mathrm{kg}$ body weight) on some indices of stress, reproduction, and milk yield in dairy cows.

\section{Materials and Methods}

The study was conducted during the summer of 2016 between June and August in an agricultural company with 850 cows of the Lithuanian Black and White breed including 720 dairy cows. Each month, between 90 and 100 calving cows were tested, of which $35 \%$ were in the first lactation. There was no calving seasonality, and the farm applied cold rearing conditions. All cows were kept in a uniform environment and received an identical ration suitable for their particular stage of lactation. Dry cows were divided into two groups according to the calving period, and different feeding rations were applied. The body condition score of calving cows was 3.5-3.75 (on a five point scale). After birth, the calves were separated from the cows within two hours. Before the study, the selected cattle were examined according to a general clinical examination plan, and were completely healthy. The experiment was carried out on 100 first-lactation dairy cows. The treatment group of cows $(\mathrm{TG}, \mathrm{n}=50)$ were given a subcutaneous injection of Rimadyl Cattle ${ }^{\circledR}(50 \mathrm{mg} / \mathrm{ml})$ solution for injection (Zoetis, Belgium) at a dose of $1.4 \mathrm{mg}$ per $1 \mathrm{~kg}$ body weight $(\mathrm{BW})$ up to one hour after calving. The control group of cows $(\mathrm{CG}, \mathrm{n}=50) \mathrm{were}$ given an injection of $0.9 \% \mathrm{NaCl}$ (B. Braun Melsungen, Melsungen, Germany). Blood tests were taken after 2, 24, and $48 \mathrm{~h}$ after calving. The blood samples were collected into vacuum test tubes (BD Vacutainer, England). The blood samples were tested with a Tosh Corporation AIA-360 using the fluorescence enzyme immunoassay method for cortisol analysis. At 305 days, the total milk yield was recorded for each cow with the help of a computerised herd management program used for data accumulation and analysis. During the study, the cows were examined according to a general clinical examination plan. The cows were monitored for signs of clinical illness, such as metritis, mastitis, and abomasum displacement, and their rectal temperature was recorded daily. Pregnancy was tested with ultrasound 'Easy Scan' between days 30 and 35 after insemination. The time to placental expulsion was noted as less than six hours, between 6 and $12 \mathrm{~h}$, and more than $12 \mathrm{~h}$ after parturition. During the investigation the following data were recorded: signs of clinical illness, the milk yield on 305 days in milk (DIM), the somatic cell count (SCC) during the first four months after calving, pregnancy rate, and blood cortisol level.

The data were analysed using the Statistical Package for the Social Sciences, 20.0. The findings were provided as mean values and standard deviations. The Pearson correlation, $\chi^{2}$ test, and linear regression equations were evaluated to define the relationship between investigated traits; $t$-test was used to define statistical differences between the two groups. The results were considered significant when $P \leq 0.05$.

\section{Results}

Significant differences $(P<0.05)$ were discovered between some diseases after calving (retained placenta, metritis, and clinical mastitis), the pregnancy rate, average milk yield on 305 DIM, mean cortisol level, and SCC during the first, second, third, and fourth months after calving. During the study, the following data were found: retained placenta in TG $10 \%$, CG 30\% $(P<0.05)$; metritis - TG $10 \%$, CG 30\% $(P<0.05)$; clinical mastitis TG $0 \%$, CG 10\% $(P<0.05)$; ketosis - TG 20\%, CG 20\%. Other clinical symptoms typical of the diseases after calving (acidosis, abomasal displacement, etc.) were not found.

In our study the TG pregnancy rate was $57.8 \%$ compared to $49.3 \%$ in $\mathrm{CG}(P<0.05)$. The calving interval in TG was 371 days $( \pm 18.9)$ compared to 414 days $( \pm 25.6)$ in CG $(P<0.05)$. The average milk yield on 305 DIM on TG was $8,752( \pm 550) \mathrm{kg}$ compared to $8,320( \pm 365) \mathrm{kg}$ in CG. The milk yield was significantly higher in the carprofen-treated group $(252 \mathrm{~kg})$ compared to the control group after treatment $(P<0.05)$. The mean cortisol level in TG two hours after calving was $51.3( \pm 24) \mathrm{nmol} / \mathrm{l}$, and in CG $44.1( \pm 22) \mathrm{nmol} / \mathrm{l}$. At $24 \mathrm{~h}$ after calving, the mean cortisol level in TG was $35.8( \pm 22) \mathrm{nmol} / \mathrm{l}$ compared to $44.1( \pm 24) \mathrm{nmol} / \mathrm{l}$ in CG (Table 1). Moreover, $48 \mathrm{~h}$ after calving, the mean cortisol level in TG was $20.7( \pm 8) \mathrm{nmol} / \mathrm{l}$ compared to $26.4( \pm 16) \mathrm{nmol} / \mathrm{l}$ in CG. After 24 and $48 \mathrm{~h}$ after calving, the cortisol level was significantly lower in TG than in CG $(P<0.05)$. The SCC during the second, third and fourth months was lower in TG than in CC $(P<0.005)$ (Table 2). 
Table 1. Differences between cortisol levels (nmol/l) during the same period.

\begin{tabular}{lccc}
\hline $\begin{array}{l}\text { Group } \\
(\mathrm{n}=50)\end{array}$ & $2 \mathrm{~h}$ & $\begin{array}{c}\text { Hours after calving } \\
24 \mathrm{~h}\end{array}$ & $48 \mathrm{~h}$ \\
\hline TG & $51.3( \pm 24)$ & $35.8( \pm 22)$ & $20.7( \pm 8)^{*}$ \\
CG & $44.1( \pm 22)$ & $44.1( \pm 24)$ & $26.4( \pm 16)$ \\
\hline
\end{tabular}

TG - treatment group (animals injected with carprofen); $\mathrm{CG}$ - control group (animals injected with $0.9 \% \mathrm{NaCl}$ ); ${ }^{*} P<0.005$

Table 2. Differences between the somatic cell counts (thousand/ml) during the same period.

\begin{tabular}{llccc}
\hline Group & \multicolumn{4}{c}{ Months after calving } \\
$(\mathrm{n}=50)$ & 1 & 2 & 3 & 4 \\
\hline TG & $147( \pm 12)$ & $98( \pm 7)$ & $73( \pm 4)^{*}$ & $67 *$ \\
CG & $129( \pm 8)$ & $217( \pm 9)$ & $229( \pm 8)$ & $142( \pm 7)$ \\
\hline
\end{tabular}

TG - treatment group (animals injected with carprofen); CG - control group (animals injected with $0.9 \% \mathrm{NaCl}$ ); ${ }^{*} P<0.005$ Based on this we can state that carprofen injection reduced the incidence of retained placenta and metritis, thereby increasing the pregnancy rate. Also Kreuger et al. (2010) detected that NSAIDs inhibit the synthesis of prostaglandin $\mathrm{F}_{2 \alpha}$ by suppressing the enzyme cyclooxygenase, which has been demonstrated to delay luteolysis and to support embryonic survival. It has been shown that $\mathrm{PGF}_{2 \alpha}$ has direct negative effects on embryonic survival and development. Similar results were obtained by Heuwieser et al. (2011) who reported that treatment with NSAIDs (e.g., ibuprofen lysinate, flunixin meglumine) might improve pregnancy rates after embryo transfer in recipient heifers.

Our research results have shown that during lactation (305 DIM), milk yields increased (252 kg). According to Carpenter et al. (2016), the early lactation treatment with NSAIDs from two different classes increased the whole lactation milk yield from between $7 \%$ and $9 \%$, with only a three-day treatment window. Our study agrees with the results of Stilwell et al. (2014), in that the total lactation yields at 305 days in milk were higher in the firstlactation cows treated with carprofen.

The results show a reduction in the level of some indicators of stress (cortisol) within $48 \mathrm{~h}$ after calving. According to Beerd et al. (2004), the assessment of plasma cortisol concentrations has been widely used as an indicator of the activation of the hypothalamic pituitary adrenal axis in response to stressful situations in cattle. Hernandez et al. (2014) found that social separation and unfamiliar surroundings are stressful situations that result in an increase in cortisol secretion in cattle. Changing housing conditions by tethering the animals in a separate area of a barn was unknown to all the animals, particularly in early lactation. Carprofen improved their general clinical condition by effective antipyrexia and restoration of the reticulorumen motility. Pang et al. (2006) detected that carprofen $(1.4 \mathrm{mg} / \mathrm{kg}$ of $\mathrm{BW})$ tended to reduce the integrated cortisol response, reducing cortisol secretion in banded animals between 6 and $12 \mathrm{~h}$ post castration. The use of carprofen reduces the incidence of clinical and subclinical disease by suppressing the cortisol response to pain. According to Negrao and Marnet (2003), cortisol is known to cause immunosuppression and, therefore, increase the risk of infection. High circulating cortisol concentrations were reported to be linked with reduced milk 
yields. Gellrich et al. (2015) found that correlation analyses indicated a significant negative association of milk cortisol and milk yield and milk yield-dependent variables (i.e. protein yield and fat yield).

We found that the SCC in TG during the second, third and fourth months was lower than in CC $(P<0.005)$. According to Du Preez (2000), when cows are stressed, cortisol secretion increases and the immune function is suppressed, including the atrophy of the immune organs and a decrease in the number of lymphocytes and acidophilic leukocytes in the blood. All of these factors lead to the inhibition of cellular immunity and resistance to disease. Similar results reported by Yang et al. (2017) show that blood cortisol levels in cattle with subclinical mastitis (milk SCC $>3 \times 10^{5}$ cells $/ \mathrm{ml}$ ) were significantly higher than in healthy cattle (milk SCC $<1 \times 10^{5}$ cells $/ \mathrm{ml}$ ).

Based on our results, it can be concluded that a subcutaneous injection of carprofen (1.4 mg per $1 \mathrm{~kg}$ of body weight) administered one hour after parturition in first-lactation cows reduces the level of some indicators of stress (cortisol) within $48 \mathrm{~h}$ after calving. During lactation (305 DIM), the intervention increased milk production $(252 \mathrm{~kg})$ and pregnancy rates $(8.5 \%)$, reduced the calving interval (43 days) and decreased the SCC during the second, third and fourth months after calving.

\section{References}

Beerd B, Kornalijnslijper JE, van der Werf JTN, Noordhuizen-Stasen EN, Hopster H 2004: Effects of milk production capacity and metabolic status on HPA function in early postpartum dairy cows. J Dairy Sci 87 : 2094-2102

Broom DM, Fraser AF 2007: Domestic Animal Behaviour and Welfare, Cabi, 4: 438 p.

Carpenter AJ, Ylioja CM, Vargas CF, Mamedova LK, Mendonça LG, Coetzee JF, Hollis LC, Gehring R, Bradford BJ 2016: Early postpartum treatment of commercial dairy cows with nonsteroidal anti-inflammatory drugs increases whole-lactation milk yield. Am Dairy Sci Assoc 99: 672-679

Du Preez JH 2000: Parameters for the determination and evaluation of heat stress in dairy cattle in South Africa. Onderstepoort J Vet Res 67: 263-271

Gellrich K, Sigl T, Heinrich HD, Wiedemann S 2015: Cortisol levels in skimmed milk during the first 22 weeks of lactation and response to short-term metabolic stress and lameness in dairy cows. J Animal Sci and Biotech 31: $1-7$

Gilbert RO, Shin ST, Guard CL, Erb HN, Frajblat M 2005: Prevalence of endometritis and its effects on reproductive performance of dairy cows. Theriogenology 64: 1879-1888

Hernandez CE, Thierfelder T, Svennersten-Sjaunja K, Berg C, Orihuela A, Lidfors L 2014: Time lag between peak concentrations of plasma and salivary cortisol following a stressful procedure in dairy cattle. Act Vet Scan 56: 1-8

Heuwieser W, Iwersen M, Goetze L 2011: Efficacy of carprofen on conception rates in lactating dairy cows after subcutaneous or intrauterine administration at the time of breeding J Dairy Sci 94: 146-151

Mainau E, Manteca X 2011: Pain and discomfort caused by parturition in cows and sows. Appl Anim Behav Sci 135: $241-251$

Negrao JA, Marnet PG 2003: Cortisol, adrenalin, noradrenalin and oxytocin release and milk yield during first milkings in first-lactation ewes. Small Rum Res 47: 69-75

Pang WY, Earley B, Sweeney T, Crowe MA 2006: Effect of carprofen administration during banding or burdizzo castration of bulls on plasma cortisol, in vitro interferon- $\gamma$ production, acute-phase proteins, feed intake, and growth. J Anim Sci 10: 2006-2527

Paull DR, Lee C, Colditz IG, Atkinson SJ, Fischer AD 2007: The effect of a topical anaesthetic formulation, systemic flunixin and carprofen, singly or in combination, on cortisol and behavioural responses of Merino lambs to mulesing. Austral Vet J 85: 98-106

Stilwell G, Limaa MS, Carvalhob RC, Broomc DM 2014: Effects of hot-iron disbudding, using regional anaesthesia with and without carprofen, on cortisol and behaviour of calves. Res Vet Sci 92: 338-341

Von Krueger X, Heuwieser W 2010: Effect of flunixin meglumine and carprofen on pregnancy rates in dairy cattle. J Dairy Sci 93: 5140-5146

Yang M, Shi J, Tian J, Tao J, Chai M, Wang J, Liu G 2017: Exogenous melatonin reduces somatic cell count of milk in Holstein cows. Scientific Reports 7: 43280 